\title{
Peranan Gereja Batak Karo Protestan dalam Mempertahankan dan Melestarikan Budaya Etnis Karo di Kabanjahe
}

\author{
Waston Malau* dan William Chandra Ginting \\ Program Studi Pendidikan Antropologi, Fakultas Ilmu Sosial, Universitas Negeri Medan
}

Diterima Agustus 2016; Disetujui Oktober 2016; Dipublikasikan Desember 2016

\begin{abstract}
Abstrak
Penelitian ini bertujuan untuk mengetahui misi Gereja Batak Karo Protestan yang berkaitan dengan pelestarian budaya, suku Karo yang menjadi jemaatnya lebih mampu mempertahankan identitasnya dari pada yang bukan. Upayanya adalah agar para jemaat mampu melestarikan dan mempertahankan budaya suku Karo. Penelitian ini menggunakan metode deskriptif kualitatif yang bertujuan untuk memahami dan menafsirkan makna dari suatu peristiwa interaksi tingkah laku manusia sehingga dapat memberikan gambaran sistematis, penelitian ini memakai objek yaitu Moderamen (pimpinan pusat) GBKP, Pimpinan Majelis Jemaat Gereja, Pendeta, Pertua, Diaken, Badan Pelestarian Budaya GBKP, dan Jemaat GBKP yang merupakan tokoh adat Karo. Teknik pengumpulan data yang digunakan dalam penelitian ini adalah observasi dan wawancara. Hasil penelitian ini adalah pelestarian budaya yang dilakukan GBKP merupakan pelestarian budaya yang tidak menentang menentang ajaran Agama Kristen Protestan. Artinya, GBKP meyakini Tuhan sebagai penyelamat bukan kepercayaan animisme ataupun dinamisme yang diyakini oleh para leluhur pada zaman dahulu ataupun pada zaman belum masuknya agama Kristen di kehihupan masyarakat Karo atau yang lebih dikenal dengan sebutan agama pemena. Bertahannya Budaya Karo pada jemaat GBKP di Kecamatan Kabanjahe disebabkan karena kebudayaan yang dilestarikan merupakan kebudayaan yang tidak bertentangnan dengan ajaran GBKP dan masih bertumbuhnya kesadaran jemaat untuk melestarikan dan mempertahankan kebudayaannya.
\end{abstract}

Kata Kunci: GBKP; Budaya Karo; Suku Karo,

\begin{abstract}
This study aims to determine the Batak Karo Protestant Church's mission with regard to the preservation of culture, Karo tribe who became his community better able to maintain their identity than not. Equally important, is that the church is able to preserve and maintain the culture of the Karo. This study used a qualitative descriptive method that aims to understand and interpret the meaning of an event interaction of human behavior so as to provide an overview of systematic, this new study used an object that is Moderamen (the central leadership) GBKP, Chairman of the Assembly Church of the Reverend, Pertua, Deacon, Agency GBKP Cultural preservation, and the Church GBKP which is the traditional leaders Karo. Data collection techniques used in this study is the observation and interviews. The result of this research is conducted GBKP cultural preservation is cultural preservation is not opposed against the teaching of Protestant Christianity. That is, GBKP believe in God as the savior not animism or dynamism which is believed by the ancestors of ancient times or at times not the coming of Christianity in society kehihupan Karo or better known as pemena religion. The persistence of Culture Karo GBKP church in the district of Kabanjahe due preserved culture is a culture that is not bertentangnan with GBKP teachings and still growing awareness of the people to preserve and maintain their culture.
\end{abstract}

Keywords: GBKP; Karo culture; Karo,

How to Cite: Malau W. dan William C.G., (2016). Peranan Gereja Batak Karo Protestan dalam Mempertahankan dan Melestarikan Budaya Etnis Karo di Kabanjahe, Anthropos: Jurnal Antropologi Sosial dan Budaya, 2 (2) (2016): 130143.

*Corresponding author:
E-mail: malauwastonantro@yahoo.co.id

p-ISSN 2460-4585

e-ISSN 2460-4593 


\section{PENDAHULUAN}

Indonesia dikenal sebagai negara yang terdiri atas berbagai macam suku bangsa. Masing-masing suku bangsa memiliki warisan budaya yang tak ternilai harganya. Menurut Koentjaraningrat (1989: 186), "Budaya merupakan wujud ideal yang bersifat abstrak dan tak dapat diraba yang ada dalam pikiran manusia yang dapat berupa gagasan, ide, norma, keyakinan dan lain sebagainya."

Setiap kebudayaan terdapat unsur-unsur yang juga dapat dimiliki oleh kebudayaan lain. Koentjaraningrat menyebutnya sebagai unsurunsur kebudayaan yang universal yang meliputi: sistem religi dan upacara keagamaan, sistem dan organisasi kemasyarakatan, sistem pengetahuan, bahasa, kesenian, sistem mata pencaharian hidup, dan sistem teknologi dan peralatan.

Secara eksplisit, budaya suatu suku bangsa lebih banyak tampak dalam hal makanan khas, pakaian adat, bahasa, kegiatan adat, dan lain sebagainya. Misalnya suku Karo yang memiliki ciri khas yang menjadi identitas mereka. Suku Karo dikenal dengan makanan khasnya, seperti BPK, cimpa, terites dan tasak telu. Gendang, Sarune, Ketteng-Ketteng, Landek sebagai bentuk kesenian dan bahasa Karo sebagai bahasa khas.

Pada hakikatnya, budaya merupakan identitas bangsa yang harus dihormati dan dijaga serta dilestarikan agar kebudayaan tersebut tidak hilang dan kelak menjadi warisan bagi generasi berikutnya. Keanekaragaman budaya di Indonesia merupakan salah satu daya tarik bangsa lain untuk mengetahui, bahkan tidak sedikit yang tertarik untuk mempelajari budaya Indonesia yang dikenal sangat unik. Kebanggaan bangsa Indonesia akan budaya yang beraneka ragam mengundang tantangan bagi seluruh rakyat untuk mempertahankan dan melestarikan budayanya agar tidak pudar bahkan dicuri oleh bangsa lain. Hal ini masih tampak dari penggunaan bahasa daerah sebagai alat komunikasi sehari-hari oleh masing-masing suku, dan kegiatan adat yang masih dilaksanakan dalam acara pernikahan, kematian, dan sebagainya.
Namun ada kalanya budaya suku tertentu di suatu daerah mengalami kelunturan atau pengikisan akibat adanya kontak dengan budaya lain. Beberapa tahun belakangan ini, kebanggaan terhadap keanekaragaman budaya cukup terusik dengan banyaknya kasus pengakuan dari pihak luar terhadap budaya Indonesia. Diantaranya adalah dibajaknya lagu Rasa Sayange dari Maluku sebagai suara latar website pariwisata Malaysia, diakuinya tari Reog Ponorogo sebagai budaya Malaysia dan telah dipatenkannya motif kerajinan perak Bali oleh pengusaha asing. Kasus-kasus pengakuan budaya Indonesia oleh pihak asing tentunya menimbulkan reaksi yang beragam dari masyarakat Indonesia. Tidak sedikit pihak yang menyalahkan pemerintah dalam kasus tersebut.

Adanya pendapat bahwa ketidakpedulian bangsa Indonesia terhadap budayanya sendiri terkait dengan makin ditinggalkannya budaya asli Indonesia terutama oleh generasi muda. Seiring berkembangnya zaman, menimbulkan perubahan pola hidup masyarakat yang lebih modern. Akibatnya, masyarakat lebih memilih kebudayaan baru yang mungkin dinilai lebih praktis dibandingkan dengan budaya lokal. Masyarakat lebih bangga menggunakan budaya asing di berbagai sektor kehidupan mulai dari permainan, hiburan sampai pola perilaku.

Demikian halnya dengan suku Karo. Pada umumnya generasi muda sudah banyak yang tidak mengenal budayanya sendiri, khususnya mereka yang tinggal di perkotaan. suku Karo yang masih mempertahankan kebudayaannya adalah masyarakat Karo yang menjadi jemaat di Gereja Batak Karo Protestan.

Gereja berasal dari bahasa portugis igreja, yang berarti kumpulan orang yang dipanggil keluar dari gelap menuju terang. Menurut KBBI, gereja merupakan badan atau organisasi umat kristen yang sama kepercayaan, ajaran dan tata cara ibadahnya. Gereja Batak Karo Protestan (GBKP) sendiri merupakan suatu perkumpulan suku Karo yang beragama Kristen Protestan.

Percakapan sehari-hari, suku Karo yang menjadi anggota GBKP masih menggunakan bahasa Karo. Demikian juga dalam hal mencari 
kekerabatan (ertutur), dan pelaksanaan kegiatan adat. Terlihat jelas perbedaan antara suku Karo anggota GBKP dengan yang bukan anggota GBKP. Pada kesempatan erbelas ras mbereken pedah (memberi nasihat), anggota GBKP akan dengan mudah memberikan nasihat dalam bahasa Karo.

Selain penggunaan bahasa daerah, ada beberapa hal yang menjadi budaya suku Karo yang selalu digunakan oleh masyarakat anggota GBKP. Benda budaya karo seperti uis nipes (sejenis ulos), pakaian adat lengkap dan kesenian seperti landek sering ditunjukkan dalam berbagai kegiatan. Kebudayaan tersebut masih digunakan oleh masyarakat Karo anggota GBKP. Berbeda dengan masyarakat Karo yang bukan anggota GBKP.

\section{METODE PENELITIAN}

Jenis penelitian yang akan digunakan dalam penelitian ini adalah adalah penelitian lapangan dengan pendekatan deskriptif kualitatif. Penelitian lapangan merupakan salah satu metode pengumpulan data dalam penelitian kualitatif. Penelitian lapangan dilakukan untuk memutuskan kearah mana penelitiannya.

Menurut Bogdan dan Tylor dalam (Moleong, 2005: 4) metode kualitatif menghasilkan data deskriptif berupa kata-kata tertulis atau lisan dari orang-orang atau pelaku yang bisa diamati. Selain melalui penelitian lapangan, dilakukan juga studi pustaka untuk menambah literatur yang relevan dengan penelitian yang dilakukan. Literatur tersebut dapat berupa buku-buku, jurnal, artikel dan tulisan-tulisan ilmiah lainnya, serta internet yang memuat berbagai karangan-karangan ilmiah mengenai hal-hal yang berhubungan dengan penelitian tersebut.

Pada penelitian kualitatif tidak menggunakan istilah populasi, tetapi oleh Spradley dinamakan "social situation" atau situasi sosial yang terdiri atas tiga elemen yaitu: tempat (place), pelaku (actor), dan aktivitas (activity) yang berinteraksi secara sinergis. Situasi sosial tersebut dinyatakan sebagai objek penelitian yang ingin diketahui "apa yang terjadi" di dalamnya (Sugiyono: 2010).

Tempat (place) atau yang sering disebut dengan lokasi penelitian, akan diadakan di Kabanjahe, Kecamatan kabanjahe, Kabupaten Karo. Pelaku (actor) atau yang sering disebut dengan informan dalam penelitian ini adalah Moderamen (pimpinan pusat) GBKP, Pimpinan Majelis Jemaat Gereja, Pendeta, Pertua, Diaken, Badan Pelestarian Budaya GBKP, dan Jemaat GBKP yang merupakan tokoh adat Karo. Sedangkan aktivitas (activity) yang dimaksud dalam penelitian ini adalah bagaimana cara berinteraksi, dan komunikasi masyarakat Kabanjahe mengingat banyaknya macam suku, agama yang ada di Kabanjahe, sehingga dengan mudah membedakan mana yang merupakan jemaat GBKP dan mana yang bukan jemaat GBKP.

Pada penelitian kualitatif, pengumpulan data dilakukan pada natural setting (kondisi yang ilmiah), sumber data primer, dan teknik pengumpulan data lebih banyak pada observasi tanpa berperan serta (observation non participant), wawancara mendalam (in depth interview) dan dokumentasi (Sugiyono, 2010).

Peneliti melakukan observasi partisipasi diluar dan didalam gereja, menggunakan lembar observasi yang telah disiapkan. Peneliti melakukan observasi non partisipasi, yaitu dilakukan oleh gereja baik di dalam dan di luar gereja. Di dalam gereja peneliti mengamati kegiatan ibadah yang dilakukan setiap minggu termasuk interaksi dan cara yang dilakukan oleh Pendeta dan Guru Sekolah Minggu mengajar untuk memperkenalkan dan melestarikan budaya Karo yang dimiliki.

Kegiatan diluar gereja peneliti mengobservasi berbagai kegiatan yang dilakukan gereja dan jemaat, baik kegiatan kerohanian seperti Penelaahan Alkitab (PA) dan kegiatan kemasyarakatan baik suka dan duka. Kegiatan suka dan duka tersebut, peneliti mengamati sejauh mana gereja berperan menujukkan keterlibatannya dan kaitannya dengan budaya Karo.

Wawancara adalah percakapan dengan maksud tertentu. Percakapan itu dilakukan oleh 
dua pihak, yaitu pewawancara (interviewer) yang mengajukan pertanyaan dan yang diwawancarai (interviewee) yang memberikan jawaban atas pertanyaan itu (Moleong, 2006).

Upaya untuk mengumpulkan data, peneliti melakukan wawancara terhadap informan yang sudah ditentukan, yakni Moderamen (pimpinan pusat) GBKP, Pimpinan Majelis Jemaat Gereja, Pendeta, Pertua, Diaken, Badan Pelestarian Budaya GBKP, dan Jemaat GBKP yang merupakan tokoh adat Karo.

Penentuan informan demikian disebut dengan purposive, artinya menentukan target kelompok (informan) secara sengaja oleh peneliti dengan berbagai pertimbangan, yang dianggap bisa memperkaya penelitian.

Teknik ini dilakukan untuk mengumpulkan berbagai data yang terkait dengan topik penelitian. Peneliti akan mengumpulkan referensi penelitian dari bukubuku dari berbagai perpustakan, dan memperoleh data tentang sejarah GBKP, program-program yang berkaitan dengan pelestarian budaya dan kegiatan yang dilakukan untuk melestarikan dan mempertahankan kebudayaan tersebut.

Untuk itu dokumen-dokumen yang dipelajari adalah dokumen berupa program kerja GBKP, baik GBKP mederamen maupun GBKP setiap Runggun. Begitu juga dengan buku dan catatan yang digunakanoleh GBKP dalam setiap aktifitasnya, seperti buku PA, buku Liturgi, dan kitab Ende-Enden dan Penambahen Ende-Enden dan juga Suplemen Enden-Enden GBKP.

Menurut Spradley (2006:131-132) langkah analisis bisa dilaksanakan setelah semua data dikumpulkan. Analisis data dilakukan setelah data-data dikumpulkan dengan lengkap melalui wawancara, bukubuku, majalah, artikel, hasil laporan penelitian, internet dan lain-lain yang berkaitan dengan topik penelitian ini.

Bogdan dan Taylor dalam Moleong (2006:6), menyatakan bahwa penelitian kualitatif menghasilkan deskripsi atau uraian berupa kata-kata tertulis dan lisan dari masyarakat pendukung dan perilaku yang diamati.

Jadi untuk mengelola data yang diperoleh dalam penelitian ini, dianalisis dengan menggunakan teknik deskriptif yaitu teknik yang digunakan untuk mendeskripsikan atau menggambarkan masalah yang diteliti dengan menggunakan uraian-uraian dan bukan dalam bentuk angka-angka.

Semua data yang diperoleh dari lapangan maupun dari buku yang terkait, diolah dan dianalisis dengan teliti. Beberapa tahap yang dapat dilakukan dalam menganalisis data, dengan 1) Menyusun data, yaitu mengatur dan mengurutkan semua hasil penelitian yang diperoleh, baik dari hasil wawancara maupun hasil dari studi pustaka. 2) Mengkategorisasikan data, yaitu mengelompokkan seluruh data yang diperoleh dilapangan selama penelitian. 4) Menginterpretasikan data yaitu interpretasi data dapat dilakukan dengan membandingkan hasil data yang telah diperoleh melalui wawancara dan hasil dari studi pustaka. 5) Menganalisis data yang dilakukan dengan menafsirkan dan menganalisis seluruh data setelah data tersebut dikategorisasikan.

Hasil olahan data dan analisis tersebut dijadikan sebagai bahan tulisan yang akan dirumuskan dan disusun secara sistematis, sehingga hasilnya dapat dilihat dalam satu laporan ilmiah atau dinamakan skripsi.

\section{HASIL DAN PEMBAHASAN}

Agama memiliki defenisi yang sangat beragam, Emile Durkheim mendefenisikan agama sebagai suatu sistem yang terpadu yang terdiri atas kepercayaan dan praktik yang berhubungan dengan hal yang suci. Menurut Kamus Besar Bahasa indonesia definisi agama adalah sistem yang mengatur tata keimanan (kepercayaan) dan peribadatan kepada Tuhan Yang Maha Kuasa serta tata kaidah yang berhubungan dengan pergaulan manusia dan manusia serta lingkungannya.

Menurut Encyclopedia of Philosophy dalam Harry (2013), agama adalah kepercayaan kepada Tuhan yang selalu hidup, yakni kepada 
jiwa dan kehendak ilahi yang mengatur alam semesta dan mempunyai hubungan moral dengan umat manusia.

Menurut Eka Darmaputra (1994) dalam Harry (2013), Sejarah awal agama Kristen dimulai dari banyaknya orang yang tidak puas dengan agama-agama yang ama dan mereka mencari jalan keselamatan dala berbagai macm kepercayaan. Maka beberapa orang masuk kedalam agama Kristen dan ikut kedalam perkembangan gereja selanjutnya. Agama Kristensudah diperkenalkan sejak berabadabad mellui Nabi Isha dan selanjutnya dikembangkan oleh St. Petrus. Agama Kristen menyebr dimulai dari Palestina lalu berkembang kedaerah Asia kecil, Laut Tengah, Yunani-Romawi, Afrika dan Germania sampai pedalaman Asia-Tiongkok. Kemudian berdirilah gerja Katolik Roma, Namun akibat reformasi gereja yang dipelopori oleh Martin Luther yang menuntut Kesucian Agama Kristen, berdirilah sekte-sekte gereja baru. Geereja-gereja tersebut beralira protestan, Baptis, Methodis, dan lain sebagainnya.

Menurut Berkhof (2011:47) dalam Harry (2013:12) "banyak orang yang beranggapan bahwa gereja hanyalah sebatas gedung. Hal tersebut bukanlah pengertiansesungguhnya dari Alkitab mengenai gereja. Kata gereja berasal dari kata Yunani "ekklesia" yang berarti "perkumpulan atau orang-orang yang dipanggil keluar". Gereja memiliki beberapa arti yaitu: Arti pertama ialah "umat" atau yang lebih tepat dikatakan persekutuan bagi umat Kristen, dan arti kedua adalah sebuah perhimpuan atau pertemuan ibadah umat Kristen. Bisa bertempat di rumah kediaman, lapangan, ruangan dihotel, maupun tempat rekreasi. Arti ketiga adalah mazhab (aliran) atau denominasi dalam agama Kristen. Gereja Katholik, gereja Protestan, dan lain sebagainya. Arti terakhir dan juga arti umum adalah sebuah"rumah Ibadah" Umat Kristen dimana umat bisa berdoa atau sembahyang."

Selanjutnya gereja dalam arti Eklesia juga berarti suatu persekutuan orang-orang yang telah dipanggil dan dipersatukan oleh Allah tanpa adanya kepentingan-kepentingan atau tujuan yang sama dari mereka untuk bersekutu. Jadi, kalo mengenai visi gereja, apapun gerejanya tentu harus digali dari visi frman Tuhan, bukan manusia yang menjadi pimpinan gegreja tersebut.

Menurut C. De Jonge dalam Harry (2013:17), titik permulaan gerja di Indonesia adalah pada zaman kedatangan orang-orang Portugis yang membawa keKristenan untuk pertama kalinya, seperti halnya diseluruh Eropa, Di Indonesa juga gereja yang pertama adalah bercorak Roma Khatolik. Akan tetap ejadian itu berlaku hanya untuk sebagian dari Indonesia Timur, Artinya hanya untuk Ambon dan Minahasa. Penyebaran injil di Indonesia berjaln dalam empat tahap, yaitu Gelombang pertama ialah kedatangan orang-orang Portugisyang mendirikan gerja Roma Khatolik di Flores. Gelombang kedua ialah kedatangan Belanda dalam rangka VOC dan menegakkan gereja-gereja di Maluku. Gelombang ketiga ialah kedatangan badan-badan pekabaran injil seperti Rheinische Mission Gesseillescehaft (RMG), Nederlands Zendelingenootschap (NZG), Basel Mission, Methodist Gereformeerd, yang menegakkan gereja-gereja HKBP, BNKP, GBKP, dan gereja Methodist. Gelombang keempat ialah badan-badan pekabarn injil yang sesudah pengakuan kedaulatan seperti gereja baptis.

Gereja Batak Karo Protestan sendiri merupakan salah satu gereja yang terbentuk dari penyebaran injil gelombang ketiga. Gereja kesukuan ini berdiri di Tanah Karo, Sumatera Utara dan melayani masyarakat suku Karo. GBKP adalah gereja Kristen Protestan yang beraliran Calvinis. Pada 18 April 1890, Nederlands Zendeling Genootschap (NZG), mengutus Pdt. H. C Kruyt dari Tomohon, Minahasa, ke Tanah Karo. Kruyt tinggal di Buluh Awar yang menjadi pos penginjilan yang pertma di Tanah Karo. tahun berikutya dia menjemput orang guru injil yaitu B. Wenas, J Pinontoan, $\mathrm{R}$ Tampenawas, dan $\mathrm{H}$ Pesik. Keempat orang inilah yang menjadi rekan Kruyt melakukan penginjilan di Karo. sebelumnya, keempat orang ini juga bekerja di daerah Minahasa, Sulawesi Utara. (Sinuraya 2004:1). 
Pada tahun 1892 Pdt H C Kruyt pulang ke negerinya tanpa berhasil membaptis seorangpun dari suku Karo. Ia kemudiandigantikan Pdt J K Wijngaarden, yang seblumnya telah bekerja di Pulau Sawu dekat pulau timor. Pendeta inilah yang melakukan pembaptisan pertama kepada suku Karo pada tanggal 20 Agustus 1893. Pada saat itu ada enam orang yang dibabtis, yaitu : Sampe, Ngurupi, Pengarapen, Nuah, Tala dan Tabar. Pada tanggal 21 September 1894 Pendeta Wijngaarden meninggal karena serangan Disentri. Pendeta Wijngaarden digantikan oleh Pendeta Joustra. Beliaulah yanng menerjemahkan 104 cerita-cerita Alkitab dari perjanjian lama dan perjanjian Baru ke dalam Bahasa Karo (104 turin-turin). (Tarigan, 2011:135).

Kemudian datang pula Pdt Henri Guillaume (utusan RMG dari Jerman) dari Seribu dolok yang sebelumnya tinggal di Tapanuli. Pada saat itu, seribu dolok merupakan aerah pelayanan gereja Batak (cikal-bakal HKBP-Huria Kristen Batak protestan). Bersama dengan pendeta Henri Gaulliame, datang pula seorang guru injil, bernama Martin Siregar. Samapai pada tahun 1900, orang Karo yang sudah dibaptis hanya 25 orang. Dalam kurun waku 10 tahun pertama tidak banyak orang Karo yang dibaptis. Ini disebabka oleh kegigihan suku Karo dalam memepertahankan tradsi dan adat istiadatnya. Mereka merasa aman hidup dalam kebudayaan yangbersifat magis, mistis dan animistis. Selain itu, perkembangan Islam di Sumatera juga turut mempengaruhi kurangnya penduduk lokal karo yang mau dibaptis. ( Sinuraya, 2004:4).

Tahun 1903, datang pula Pdt E. J van den berg dan J. H Neumann yanng kemudian membuka ppos baru dan menetap di Kabanjahe. Mereka membuka rumah sakit Zending di Sibolangit dan di Kabanjahe. Mereka juga bekerja sama dengan pihak pemerintah Pdt E. J Van den Berg membuka rumah sakit kusta di Lau Simomo, sementara J H Neumann aktif membuka pekan-pekan (sejenis pasar di desadesa) di daerah Deli hulu.
Tahun 1906 datang Pdt G Smith dan membuka kweek school (sekolah guru) di Berastagi. Sekolah ini kemudian dipindahkan ke Raya, dan akhirnya tutu pada tahun 1920, kemudian guru-guru sekolah yang telah terdidik di tmpatkan di desa-desa enjadi guru unutk mengabarkan innjil. Selanjutnya, Prof DR $\mathrm{H}$ Kremer meninjau tempat-tempat zending di Karo dan mengusukan dalam waktu sesingkatsingkatnya jemaat Karo yang dihasilkan dari pekabaran injil mempersiapkan diri untuk berdiri sendiri. Dalam ranngka kemandirian ini, tenaga-tenaga pribumi disekolahkan untuk menjadi pendeta. Selin itu, ditunjuk juga majellis jemaat yang sudah mampu untuk memimin dan mengembangkan jemaat yang lain. Pada tahun 1940, dua guru injil P Sitepu dan TH. Sibero dikirm ke sekolah pendeta di seminari HKBP, Sipoholon.

Pada periode ini berkembang pula pergerakan muda-mudi di tengah-tengah gereja dennngan nama Christelijkemeisjes club maju (CMCM) untuk kaum perempuan dan Bond Kristen dilaki karo (BKDK) untuk kaum laki-laki di kalangan pemuda Kristen Karo. kedua pergerakan ini dapat dikatakan sebagai embrio lahirnya perkumpulan pemuda-pemudi GBKP, yang disebut persadaan man anak gerjanta (permata). Pengesahan dan peresmian permata dilaksanakn oleh Moderemen GBKP pada tanggal 12 September 1948 yang diperingati sebagai hari jadi permata GBKP.

Guru injil yang di sekolahkan ke Seminari Sipoholon (Tarutung) menyelesaikan studinya pada pertengahan sidang sinode pertama, yang menetapkan nama Gereja Batak Karo protestan (GBKP) di Sibolangit tanggal 23 Juli 1941. Pada saat yang sama, ada penahbisan dua orang pendeta pertama dari suku Karo yaitu Pdt Palem Sitepu dan Pdt Thomas Sibero. Pad sinode pertama ini juga, tata gereja GBKP yang pertama dan ketua moderamen GBKP, Pdt J Van Muylwijk ditetapkan. Sekretarsi moderamen adalah guru Lucius Tambun (Periode 19411943). Pdt P sitepu ditempatkan di Tiga Nderket sebagai wakil ketua klasis untuk daerah Karo Gugung (dataran tinggi) dan Pdt 
Th Sibero di Peria-ria sebagai wakil ketua klasis daerah karo Jahe. (Sinuraya 2004:6).

Menurut badan statistikk GBKP tahun 2014 Gereja Batak karo Protestan mempunyai 22 klasis, 533 runggun, 834 Gereja, dan sekitar 302.227 Jiwa anggota jemaat gereja GBKP yang tersebar di NAD, Sumatera, Jawa, Bali, Kalimantan, Sulawesi serta di Simpang Tanjung (perbatasan Indoensia-Malaysia). Untuk memenuhi kebuthan rohani setiap jemaat maka GBKP dilayani oleh 394 Pendeta dan 121 Pelayan lainnya yang terdiri dari vicaris, calon vicaris, detaser, dan pegawai administrasi moderamen.

Kepengrusan pusat Gereja batak karo protestan disebut moderamen atau yang lebih familiar disebut sebagai sinode. GBKP mengelola sejumlah yayasan antara lain : yayasan Pendidikan Kristen GBKP, yayasan Taman Kanak-kanak GBKP, badan pengembangan ibadah dan musik Gereja (BPIMG), Retreat Center, yayasan gelora kasih di Suka Makmur, Yayasan Panti Asuhan Kristen GBKP Alpha Omega, Yayasan Sosial GBKP, Yayasan Ate Keleng, Yayasan Wisata Rohani GBKP, Warta Gereja Maranatha (WGM) dan Asrama Pemuda GBKP Maranata. (Tata Gereja GBKP 2005: 55)

Selain itu, kategorial pelayanan gerjani dalam GBKP ada lima yaitu: 1) Kategorial kaum ibu, yang disebut Moria GBKP, 2) Kategorial kaum Bapak, yang disebut Mamre GBKP, 3) Kategorial kaum pemuda-pemudi, yang disebut permata GBKP, 4) Kategorial anak-anak dan remaja, yang disebut KA-KR GBKP, 5) Kategorial orang tua lanjut usia yang disebut Lansia GBKP

Gereja Batak Karo Protestan adalah gereja kesukuan yang tentunya memiliki visi dan misi dalam pelayanan. Gereja yang pelayanannya berbasis pada masyarakat Karo yang memiliki ikatan sosial dan kekeluargaan yang kuat menyadari bahwa kedatangan Injil pada masyarakat Karo membutuhkan sesuatu perbuatan kasih oleh gereja yang bisa langsung dirasakan oleh masyarakat, khususnya masyarakat suku Karo tersebut. GBKP menyadari hal ini, sehingga dirumuskan misi gereja untuk mencapai visi yang mengarah dan mendukung pelayanan-pelayanan diakonia. Pelayanan diakonia adalah pelayanan yang dilakukan berdasarkan kasih dan tidak mengharapkan imbalan.

Pelayanan diakonia ini diberikan kepada semua jemaat tanpa terkecuali baik dalam keluarga, jemaat secara teritorial (Sektor/PJJ, Majelis jemaat/Runggun, Klasis, Sinodal, Ekumenial) maupun secara kategorial usia/gender (KA/KR, Permata, Moria, Mamre) dan kategorial profesi (petani, pedagang, pengajar, penegak hukum, pelayan kesehatan, politisi, birokrat, bidang jasa angkutan, teknik, finansial, konsultan, dan lain sebagainya).

Untuk mewujudkan visi gereja GBKP ini, maka sidang sinode GBKP menetapkan visi GBKP tahun 2010-2015 yaitu : "Nggeluh lah bagi kula Ni Kristus (Berlaku sebagai Tubuh Kristus)". Dan mewujudkan visi tersebut, maka GBKP membuat beberapa misi. Misi yang dibuat mengarah pada pelayanan diakonia agar dapat langsung tetap sasaran ke jemaat GBKP.

Misi GBKP untuk mewujudkan visi gereja adalah: 1) Meningkatkan spiritualitas jemaat. 2) Meningkatkan teologia dan peribadahan jemaat. 3) Meningkatkan penghargaan terhadap kemanusiaan sehingga munculnya rasa solidaritas dan berbudaya. 4) Meningkatkan penegakan kebenaran, keadilan, kejujuran dan kasih. 5) Meningkatkan jumlah jemaat yang dapat dipercaya. 6) Meningkatkan perekonomian jemaat.

Enam misi GBKP dijabarkan dalam lima tahun periode kerja pelayanan ini GBKP. Ke lima misi ini dilakukan berdasarkan prioritas yang dijabarkan di dalam program tahunan, sehingga dari tahun 2011-2015 prioritas tersebut dilakukan secara bertahap, yaitu: 1) Tahun 2011: Peningkatan Teologia, Spiritualitas Dan Mutu Ibadah, 2) Tahun 2012: Peningkatan Solidaritas Internal GBKP, 3) Tahun 2013: Peningkatan Solidaritas Eksternal (Ekumene Gereja Dan Masyarakat), 4) Tahun 2014: Peningkatan kwantitas SDM yang berkwalitas, 5) Tahun 2015: Peningkatan sosial, Ekonomi dan Budaya Jemaat.

Penekanan atas visi dan misi adalah agar setiap warga menyadari bahwa dialah Gereja 
itu, dialah bagian dari tubuh Kristus. Tujuannya agar: 1) Transformasi pribadi tiap orang menjadi murid Kristus. (Mat 28:19-20), 2) Terjadi Mendudukan pengertian Gereja yaitu gereja adalah orangnya, 3) Gereja mampu berdampak di dan bagi dunia baik dalam relasi antar gereja (intra church) dan antar kepercayaan (inter faith), 4) Meningkatkan Solidaritas, dan mengerti serta memberlakukan apa artinya solidaritas Kristus bagi seluruh ciptaan (Sumber: Garis Besar Pelayanan Gereja Batak Karo Protestan 2010-2015).

Setiap satu priode, visi dan misi gereja berubah-ubah. Alasan berubahnya visi dan misi tersebut setiap tahun dan periodenya adalah keadaan jemaat itu sendiri. Moderamen dan Badan Pekerja Klasis melihat, mempertimbangkan dan memutuskan program, visi dan misi yang dibutuhkan sesuai dengan kebutuhan jemaat.

Penekanan visi dan misi gereja ini tentunya sejalan dengan hakikat gereja yang sebenarnya, bahwa gereja adalah orangnya. Maksudnya, gereja bukanlah sekedar gedung dan bangunannya, tetapi gereja tersebut adalah orang-orang yang bersatu dan memiliki visi dan misi yang sama. Gereja adalah orangnya juga dapat diartikan bahwa bagaimanapun gereja tersebut, baik kualitas dan identitas gereja itu sendiri dapat dilihat dari orang-orang atau jemaat yang menjadi anggota gereja. Sehingga jelaslah dapat dilihat kenyataannya bahwa gereja harus dilihat dari orang yang tergabung didalamnya, bukan sekedar dilihat dari gedung dan bangunan tempat ibadah dilakukan.

Selain itu dengan menyematkan kebudayaan suku Karo dalam programprogram GBKP telah menunjukkan identitas jemaat GBKP di tengah-tengah masyarakat. Visi, misi serta program yang telah dibuat Gereja Batak Karo Protestan secara sinodal harus diikuti oleh semua anggota jemaat GBKP dimanapun berada. Terutama penekanan budaya sebagai identitas masyarakat Suku Batak Karo yang sudah mulai terkikis di jemaat perkotaan.

Kebudayaan merupakan keseluruhan sistem, gagasan, tindakan dan hasil karya manusia dalam rangka kehidupan masyarakat yang dijadikan milik diri manusia dengan belajar (Koentjaraningrat, 1969:93). Hal ini berarti bahwa hampir seluruh tindakan manusia adalah kebudayaan. Sebagai sebuah suku, Suku Batak Karo juga memiliki kebudayaan yang secara turun temurun terus dilestarikan. Gereja Batak Karo Protestan adalah salah satu lembaga atau gereja kesukuan yang melakukan pelestarian kebudayaan.

Pelestarian budaya yang dilakukan GBKP adalah pelestarian budaya yang tidak menentang ajaran Agama Kristen Protestan. Artinya, GBKP meyakini Tuhan sebagai Penyelamat bukan kepercayaan animisme ataupun dinamisme yang diyakini oleh para leluhur pada zaman dahulu atau pada zaman belum masuknya agama Kristen dikehidupan masyarakat Karo atau yang lebih di kenal dengan sebutan agama Pemena.

Beberapa kebudayaan yang masih dan terus dilestarikan oleh Gereja Batak Karo Protestan adalah pertama, bahasa Karo sebagai bahasa yang sudah digunakan sejak dahulu, saat ini masih terus digunakan dan dilestarikan oleh masyarakat Karo khususnya masyarakat Karo yang menjadi jemaat GBKP. Selain sebagai alat komunikasi, penggunaan bahasa Karo juga bertujuan untuk menunjukkan identitas.

Hasil wawancara peneliti dengan narasumber Pdt. Durmanis Sembiring Pandia S.Th, bahwa Bahasa Karo akan tetap digunakan dalam kegiatan gereja termasuk Khotbah, Kebaktian Minggu Umum, Remaja dan terlebih Kepada anak KA-KR ataupun kegiatan-kegiatan keagamaan lainnya seperti PA mamre, PA Moria, PA Permata, PA KA-KR dan lain sebagainya supaya masyarakat Karo khususnya jemaat GBKP tidak lupa akan identitasnya, daerah asalnya, dan terlebih kepada anak KAKR harus dibiasakan dari usia dini supaya para anak KA-KR tidak lupa akan bahasa dan budayanya sendiri yaitu budaya Karo.

Hasil wawancara peneliti dengan Pdt. Durmanis Sembiring Pandia S.Th, maka dapat diketahui pentingnya melestarikan budaya Karo terutama kepada anak KA-KR yang harus lebih ditonjolkan dimana pelestarian budaya harus 
diawali dari usia dini khusunya dibidang bahasa, supaya anak KA-KR paham dan mengerti akan pengucapan dan arti bahasa Karo. dan tidak lepas juga kepada Mamre, Moria, Permata, Remaja agar tetap melestarikan bahasa Karo, Karena bagaimanapun anak usia dini akan mengikuti apa yang dia lihat.

Kedua adalah kesenian yang masih dilestarikan GBKP adalah landek (seni tari), dimana salah satu gereja tempat penelitian peneliti, seni tari seperti tari lima serangkai masih dilestarikan kepada anak anak KA-KR, dan PERMATA. Selain dari seni tari GBKP juga masih melestarikan kesenian lain yaitu seni ukir seperti, ret-ret, dan beberapa alat musik yang dikombinasikan dengan alat musik gereja.

Ketiga adalah Pakaian Adat merupakan ciri khas yang ada didalam suatu suku bangsa yang menujukkan daerah atau asal suatu suku bangsa. Begitu juga halnya dengan budaya suku Karo yang ada di Kecamatan kabanjahe. Pakaian adat budaya suku Karo juga tetap dilestarikan oleh GBKP baik itu didalam atau diluar kegiatan gereja. Pakaian adat yang masih dilestarikan oleh GBKP yaitu tudung (penutup kepala untuk perempuan), uis nipes (selendang atau ulos yang ada di suku Batak Toba yang dikenakan oleh kaum perempuan, bulangbulang (penutup kepala untuk laki-laki), beka buluh (kain yang dikenakan oleh pria berada dibahu laki-laki).

Gereja Kristen Karo yang kemudian dikenal dengan Gereja Batak Karo Protestan (GBKP) berkembang sekalipun sangat lambat. Dari Buluh Awar penginjilan berkembang ke wilayah sekitarnya. Selanjutnya ke Kabanjahe, dan wilayah lain di dataran tinggi Karo. Seterusnya ke daerah Pancur Batu tahun 1927. Daerah Langkat dimulai penginjilan tahun 1921 dan gereja pertama ditakbiskan tahun 1929. Di Medan sudah ada kebaktian tahun 1937 dan di Jakarta tahun 1939 sudah ada perkumpulan masyarakat Karo Sada Kata dan di Bandung perkumpulan masyarakat Karo Sada Perarih. (http://gbkpkjb.org/index.php?option=com_co ntent $\&$ view=article\&id=20\&Itemid $=106, \quad$ di upload tanggal 06 maret 2015, jam 22.45 WIB.)
Hasil wawancara peneliti dengan ibu atau Hal senada juga disampaikan oleh Pdt. Nurbetty br Ginting M.Th, bahwa: Berdirinya Gereja Batak Karo Protestan di Kabanjahe yang merupakan perkembangan dari GBKP pertama yang berada di Buluhawar yang kemudian berkembang di Kabanjahe yang mana gereja mula-mula yang ada di Kabanjahe yaitu Gereja Batak Karo Protestan Kota atau sering disebut GBKP Kota Klasis Kabanjahe.

Berdirinya Gereja Batak Karo Protestan di Kabanjahe tidak terlepas dari berdirinya gereja mula-mula di Buluhawar yang kemudian berekembang ke Kabanjahe dan semua daerah di dataran tinggi Karo.

Penduduk Kecamatan Kabanjahe, termasuk masyarakat yang heterogen. Daerah ini dihuni oleh masyarakat dari berbagai latar belakang suku bangsa. Hal ini tentunya membuat masyarakat yang berada di kecamatan Kabanjahe mudah dipengaruhi oleh modernisasi dan globalisasi. Modernisasi dan globalisasi adalah salah satu hal yang mengakibatkan terkikisnya budaya khas yang dimiliki masing-masing masyarakat.

Terkikisnya budaya suatu masyarakat khususnya masyarakat Karo sangat jelas terlihat dalam kehidupan sehari-hari, terlebih bagi masyarakat Karo yang bukan jemaat GBKP. Hasil wawancara peneliti dengan beberapa teman yang bukan jemaat GBKP, dapat dilihat jelas bahwa dalam berkomunikasi mereka sudah mencampurkan bahasa Indonesia dan Bahasa Karo, bahkan ada juga beberapa teman yang sama sekali tidak mengerti bagaimana pengucapan dan makna/arti dalam bahasa Karo. Hal ini juga berdasarkan hasil wawancara dengan Milia Srikanti Tarigan, Pemuda karo yang bukan jemaat Gereja Batak Karo Protestan adalah adanya kesulitan berkomunikasi dengan menggunakan bahasa Karo karena di dalam ibadah agama Islam tidak menggunakan bahasa Daerah dan di dalam keluarga juga, saya dan keluarga tidak lagi menggunakan bahasa Karo akan tetapi menggunakan bahasa Indonesia. Setelah tamat Sekolah Menengah Pertama (SMP) saya melanjutkan sekolah di salah satu Pesantren yang ada di Kota Medan. 
Hasil wawancara peneliti dengan Milia Srikanti Tarigan, dapat dillihat bahwa sejak beliau dan anggota keluarganya menjadi umat Muslim, kegiatan yang berkaitan dengan budaya Karo sudah sangat jarang dilaksanakan.

Hasil wawancara lain peneliti dengan Johanes Purba yang bukan jemaat Gereja Batak Karo Protestan yaitu bahwa beliau sedikit mengerti akan makna/arti di dalam bahasa karo akan tetapi didalam percakapan seharihari yang menggunakan bahasa Karo, beliau kurang paham dalam pengucapan berbahasa Karo. Sehingga didalam percakapan sehari-hari dengan teman sebaya atau teman sepermainan, beliau sering menggabungkan bahasa karo dengan bahasa Indonesia. Bertujuan untuk, selain dari memperakrab hubngan dengan teman sebaya beliau juga berusaha agar memahami betul akan berbahasa karo.

Berbeda halnya dengan masyarakat Karo yang menjadi jemaat GBKP di kecamatan Kabanjahe yang lebih mampu mempertahankan dan melestarikan kebudayaannya. Hal dapat dilihat dari benda budaya yang digunakan dalam kegiatan gereja, kegiatan suku-duka jemaat, dan kegiatan lainnya. Uis nipes dan Beka Buluh(kain tenunan khas Suku Karo). Benda budaya ini adalah salah satu benda yang menunjukkan identitas seseorang dari suatu suku.

Menurut Arnold Dashefsky dalam buku A. Ubaidilah, dkk.(2000) identity (identitas) atau jati diri dapat mempunyai arti, yaitu: pertama, identitas atau jatidiri menunjuk pada ciri-ciri yang melekat pada diri seseorang atau sebuah benda.Kedua identitas atau jatidiri berupa surat keterangan yang dapat menjelaskan pribadi seseorang dan riwayat hidup seseorang.

Dari hasil wawancara peneliti dengan bapak Pdt. Durmanis Sembiring Pandia, bahwa masyarakat Karo yang berjemaat GBKP lebih mampu mempertahankan kebudayannya dibandingkan dengan masyarakat Karo yang bukan jemaat GBKP. Alasannya, suku Karo yang berjemaat GBKP baik didalam maupun diluar dataran tingi Karo, mereka akan mengerti bagaimana berkomunikasi dengan menggunakan bahasa Karo. Karena GBKP tetap menggunakan bahasa Karo sebagai alat komunikasi baik itu didalam maupun diluar kegiatan gereja. Misalnya suku Karo yang menjadi jemaat GBKP yang ada di Jakarta, Bandung dan lain sebagainya GBKP masih menggunakan bahasa Karo baik itu tata ibadah, Kitab Ende-Enden, Penambahen Ende-Enden, Suplemen dan khotbah serta kegiatan-kegiatan gereja lainnya.

Berbeda halnya dengan suku Suku Karo yang bukan jemaat GBKP. Misalnya kharismatik, di dalam kegiatan-kegiatan gereja baik itu khotbah, tata ibadah dan lain sebaginya, mereka sudah menggunakan bahasa Indonesia sebagai pedoman mereka. Contoh lain seperti Khatolik, di dataran tinggi Karo suku Karo yang berjemaat Khatolik memang masih menggunakan bahasa Karo didalam nyanyian dan Khotbah gereja. Akan tetapi suku Karo yang berjemaat Khatolik yang tinggal di luar dari dataran tinggi Karo maka tata ibadah, nyanyian, dan khotbah serta kegiatan gereja lainnya pasti menggunakan bahasa Indonesia. Karena banyaknya suku-suku lain yang beribadah di gereja tersebut. Dengan arti lain, agama Khatolik menyesuaikan bahasa yang digunakan dengan lokasi/tempat dia berada.

Hasil wawancara peneliti dengan Bapak Pdt. Durmanis Sembiring Pandia S,Th, maka suku Karo yang berjemaat GBKP lebih mampu mempertahankan kebudayannya dibandingkan dengan suku Karo yang bukan jemaat GBKP, karena suku Karo yang bukan jemaat GBKP seperti jemaat Kharismatik tidak lagi menggunakan bahasa Karo sebagai alat komunikasi dalam kegiatan-kegiatan baik itu didalam maupun di luar gereja. Dan jemaat lain seperti jemaat Khatolik dimana gereja Khatolik lebih menyesuaikan terhadap tempat atau lokasinya berada.

Penggunaan musik gereja di setiap kegiatan ibadah, GBKP juga menunjukkan kemampuannya dalam melestarikan dan mempertahankan kebudayaannya dizaman modern seperti saat ini. Kitab Ende-Enden GBKP, Penambahen Ende-Enden GBKP dan Suplemen GBKP (buku yang berisikan lagu rohani yang digunakan dalam kegaitan GBKP), 
dan tata ibadah serta Khotbah yang digunakan dalam bahasa Karo.

Hasil observasi peneliti ke gereja GBKP yang terdapat di Kecamatan Kabanjahe, maka GBKP menyadari Kebudayaan Karo harus tetap dilestarikan. Karena apabila tidak dilestarikan maka kebudayaan Karo lambat laun akan menghilang melihat begitu pesatnya perkembangan-perkembangan zaman yang sangat jauh dari unsur-unsur nilai-nilai budaya dan unsur keagamaan.

Mengingat derasnya arus erosi budaya yang terjdi akibat modernisasi dan globlisasi membuat GBKP yang ada di kecamatan Kabanjahe semakin bertekad melestarikan dan mempertahankan kebudayaan suku Karo. maka dari itu, GBKP yang ada di kecamatan Kabanjahe membuat kegiatan dan upaya untuk melestarikan kebudayaan secara berkesinambungan.

Kegiatan dan upaya tersebut terlihat dari dipertahankannya kebudayaan khas suku Karo yang tidak bertentangan dengan ajaran agama Kristen. Pelestarian budaya yanga dilakukan oleh GBKP terwujud dalam dua bentuk pelestarian budaya, yaitu: Cultur Cnouledge dan Culture Experince (Sumber: Skripsi Yolanda Rafella S.Pd)

Culture Experince merupakan pelestarian budaya yang dilakukan dengan cara terjun langsung kedalam sebuah pengalaman kultural, sehingga diharapkan jemaat GBKP kecamatan Kanbanjahe dapat melestarikan budayanya melalui ikut langsung dalam pelestarian budaya. Kegiatan dan upaya yang dilakukan GBKP yang termasuk dalam bentuk Culture Experience adalah, pertama bahasa.

Untuk setiap kegiatan ibadah umum di tengah-tengah gereja yang ada di kecamatan Kabanjahe, bahasa Karo tetap digunakan dan diusahakan terus dalam berbagai kegiatan. Dari hasil observasi peneliti di tiga belas desa/kelurahan yang ada di kecamtan Kabanjahe, untuk ibadah kebaktian yang berbahasa Karo, semua kata-kata, tata ibadah, nyanyian, Alkitab yang digunakan, Khotbah, hingga doa pun dilakukan dengan menggunakan bahasa Karo..
Terlebih kepada anak KA_KR yang selalu di dorong untuk menggunakan bahasa Karo. Karena pelestarian budaya harus dimulai dari usia sejak dini. Dari hasil wawancara peneliti, Morinta Tarigan sebagai salah satu guru sekolah minggu berpendapat bahwa bahasa Karo sangatlah penting dilestarikan kepada anak KA-KR atau anak sekolah minggu.

Beliau mengatakan "pelestarian budaya khusunya dibidang bahasa sangat lah penting dilestarikan kepada adek-adek sekolah minggu dengan cara yaitu berkhotbah, Doa Bapa Kami, nyanyian-nyanyian sekolah minggu, PA KA-KR serta kegiatan-kegiatan lainnya tetap menggunakan bahasa Karo.Karena,apabila tidak dilestarikan maka adik-adik sekolah minggu akan kesulitan berbahasaKaro. Dikarenakan, mayoritas dilingkungan tempat tinggal dan sekolah serta teman sepermainan mereka tidak lagi menggunakan bahasa resmi Karo melainkan sudah menggunakan bahasa Indonesia. Maka dari itu pelestarian budaya khususnya dibidang bahasa agar tetap dilestariakan dan dipertahankan kepada generasi-generasi putra-putri Karo agar tidak lupa akan identitasnya sebagai suku Karo."

Tidak hanya pada ibadah hari minggu saja bahasa Karo tersebut digunakan, bahasa Karo juga kerap digunakan dalam berbagai kegiatan rohanidiluar gereja. Misalnya pada ibadah PA (Penelaahan Alkitab) Moria (perkumpulan kaum ibu), mamre (perkumpulan kaum bapak), Permata (perkumpulan muda-mudi) dan PJJ (perpulungen Jabu-Jabu) yaitu gabungan kebaktian perkumpulan bapak dan ibuk. Buku bimbingan PA, Alkitab, nyanyian, Khtobah dan doa dingunakan dalam bahasa Karo.

Tidak hanya itu saja, penggunaan bahasa Karojuga dilakukan dalam ibadah kebaktian suka mapun duka. Misalnya pada saat pemberkatan pernikahan. Tata ibadah yang digunakan, nyanyian, doa pengucapan janji pernikahan menggunakan bahasa Karo.

Kedua adalah kesenian, yaitu Beberapa kesenian yang masih dilestarikan GBKP adalah landek (seni tari), dimana salah satu gereja tempat penelitian peneliti, seni tari seperti tari 
lima serangkai masih dilestarikan kepada anak anak KA-KR, dan PERMATA.

Beberapa gereja sudah lebih maju dalam melakukan upaya pelestarian dan pemertahanan budaya khas Karo. Adapun kegiatan dan upaya yang dilakukan GBKP yang ada di kecamatan Kabanjahe seperti porseni. Dimana kegiatan porseni ini merupakan salah satu kegiatan GBKP yang diikuti oleh PERMATA (muda-mudi) GBKP yang menampilkan pertandingan landek (seni tari), Vokal Group dengan menggunakan perpaduan alat musik tradisional dan modern dan lain sebagainya. PERMATA (muda-mudi) akan saling bersaing menampilkan tarian dan vokal group terbaik dari tiap-tiap grup.

Kegiatan porseniini pemuda gereja yang berpakaian adat lengkap (rose) melakukan landek. Dengan demikian para pemuda tersebut sudah terjun langsung kedalam pengalaman kultural, dan sebagai penerus dapat merasakan dan diharapkan tumbuh rasa cinta akan budaya yang dimiliki.

Selain dari seni tari GBKP juga masih melestarikan kesenian lain yaitu seni ukir seperti, ret-ret. Saat melakukan penelitan, peneliti sangat tertarik melihat keunikan dari salah satu gedung gereja yang sangat mencirikan bahwa gereja itu adalah gereja khas suku Karo. Gereja itu adalah Gereja Simpang Enam Kecamatan Kabanjahe. Tiang-tiang teras gedung gereja tersebut berhiaskan ret-ret atau ukiran khas suku Karo. Ret-ret tersebut adalah kesenian khas suku Karo yang menghiasi setiap tiang teras yang memiliki arti khusus bagi masyrarakat Karo.

Untuk kegiatan yang berlangsung diluar gereja, misalnya acara suka dan duka jemaat, gereja terus berperan serta dalam kegiatan tersebut. Untuk acara suka misalnya, warga jemaat akan ikut berperan serta membantu dan menghadiri kegiatan tersebut. pada saat menghadiri jemaat selalu menggunakan uis gara dan kampuh. Selain itu pada saat acara pernikahan, gereja akan memberikan luah atau bingkisan berupa barang seperti Alkitab. Hal ini merupakan salah satu contoh pelestarian kebudayaan.
Culture Knowledge merupakan pelestarian budaya yang dapat difungsionalisasi kedalam banyak bentuk. Tujuannya adalah untuk edukasi ataupun untuk kepentingan pengembangan kebudayaan itu sendiri. Dalam hal ini, kegiatan dan upaya GBKP yang termasuk kedalam Culture Knowledge adalah tersedianya seksi budaya dibeberapa Gereja Batak Karo Protestan yang ada di Kecamatan Kabanjahe. Seksi budaya ini bertugas sebagai petugas yang memberikan informasi tentang kebudayaan khas Karo.

Hasil wawancara peneliti dengan bapak Pdt. Durmanis Sembiring Pandia S.Th, bahwa GBKP mempunyai Biro Penggalian, Pelestarian dan Pengembangan Budaya (BP3B). BP3B memiliki beberapa peran penting dalam pengembangan budaya yaitu: 1) Menggali dan Mengembangkan budaya ke sekolah-sekolah, ke klasis-klasis yang 22 dengan cara sosialisasi, lokakarya dan lain sebagainya. Dan melakukan rapat dengan seluruh Ketua dan BP Klasis dan lembaga-lembaga kategorial. 2) Membangun Museum GBKP tahun 1990, di Sukamakmur, dimana BP3B talah membangun perkampungan Karo dizaman dahulu. Seperti rumah adat siwaluh Jabu(rumah adat Karo), jambur silima merga (jambur khas Karo), dan pola hidup masyarakat Karo di zaman dulu seperti, pergulan (membuat gula), pancur siwah, peternakan dan lain sebagainya. 3) Melalui bimbingan-bimbingan, setiap tahun GBKP mengeluarkan buku bimbingan seperti buku bimbingan moria, mamre, PJJ, permata, KA-KR, dimana didalam buku bimbingan tersebut GBKP selalu menyinggung kebudayaan di dalam tematema buku bimbingan tersebut.

Pecanangan tahun budaya di tahun 2015, yaitu peningkatan sosial, ekonomi, Dan budaya jemaat. Kehidupan sosial masyarakat karo pada zaman dahulu yang masih kental dengan budaya karo diaktualisasikan kembali ke zaman sekarang ini, karena GBKP melihat terkikisnya sosial budaya masyarakat Karo zaman sekarang akibat pengaruh budaya asing.

Biro tersebut telah memberikan suatu bukti nyata dalam pelestarian budaya dengan membuat sebuah museum di Retreat Center 
Sukamakmur yang menjadi pusat kegiatan GBKP secara sinodal.

Museum merupakan suatu lembaga yang sifatnya permanen. Museum bukan mencari keuntungan, melainkan melayani masyarakat, jemaat dan terbuka untuk umum. Tugas museum GBKP adalah mengumpulkan, menjaga, mengkomunikasikan serta memamerkan kebudayaan kebudayaan Karo untuk studi dan pendidikan serta keterangan atau bukti-bukti material beserta kelengkapannya untuk kesegaran iman.

Tujuannya adalah untuk melestarikan dan memakai bukti material manusia dan lingkungannya, membina dan mengembangkan seni, ilmu dan teknologi agar semakin besar pemikiran orang akan nilai-nilai budaya dalam melanjutkan kehidupan suatu bangsa. Museum GBKP ini sekaligus juga bertugas menyajikan dan menginventarisir tentang sejarah pekabaran injil dan pertumbuhan gereja GBKP ditengah-tengah masyarakat Karo, untuk menambah semangat missioner generasi demi generasi untuk mencari Tuhan agar menjalani hidupnya setia kepadaNya serta menghargai sejarah pekabaran injil dan sejarah kemanusiaan.

Museum GBKP bukan hanya melestarikan atau konservasi nilai-nilai budaya tapi juga pusat pendidikan, pusat penelitian, jaringan informasi dan pusat rekreasi kepada jemaat dan pengunjung lain. Museum ini berisikan benda-benda atau materi budaya yan pernah ada dikalangan Karo, bukti-bukti tentang budaya Karo, buku-buku tentang Karo dan gereja yang pernah ada. Selain itu BP3B juga mengadakan seminar tentang museum dan menyediakan narasumber untuk kebudayaan Karo. dengan demikian, Gereja Batak Karo Protestan telah melakukan Culture Knowledge dalam hal pelestarian budaya. Artinya GBKP telah menyediakan museum dan seksi budaya sebagai pusat informasi dan pendidikan tentang kebudayaan suku Karo.

\section{KESIMPULAN}

Gereja Batak Karo Protestan adalah gereja Kristen yang melayani masyarakat Suku
Karo. GBKP pada tanggal 18 April $1890 \mathrm{di}$ Buluhawar kemudian berkembang ke kabanjahe. Namun seiring perkembangan jemaat, GBKP berkembang keberbagai daerah baik didesa maupun dikota. Hasil penelitian didapat kesimpulan yaitu:

Gereja Batak Karo Protestan adalah gereja kesukuan yang tentunya memiliki visi dan misi dalam pelayanan. Gereja yang pelayanannya berbasis pada masyarakat Karo yang memiliki ikatan sosial dan kekeluargaan yang kuat menyadari bahwa kedatangan Injil pada masyarakat Karo membutuhkan sesuatu perbuatan kasih oleh gereja yang bisa langsung dirasakan oleh masyarakat, khususnya masyarakat suku karo tersebut.Untuk mewujudkan visi gereja GBKP ini, maka sidang sinode GBKP menetapkan visi GBKP tahun 2010-2015 yaitu: "Nggeluh lah bagi kula NiKristus (Berlaku sebagai Tubuh Kristus)". Dan mewujudkan visi tersebut, maka GBKP membuat beberapa misi. Misi yang dibuat mengarah pada pelayanan diakonia agar dapat langsung tetap sasaran ke jemaat GBKP.

Pelestarian budaya yang dilakukan GBKP adalah pelestarian budaya yang tidak menentang ajaran Agama Kristen Protestan. Artinya, GBKP meyakini Tuhan sebagai Penyelamat bukan kepercayaan animisme ataupun dinamisme yang diyakini oleh para leluhur pada zaman dahulu atau pada zaman belum masuknya agama Kristen di kehidupan masyarakat Karo atau yang lebih dikenal dengan sebutan agama Pemena.

Kegiatan dan upaya yang dilakukan GBKP yang ada di kecamatan Kabanjahe seperti porseni. Dimana kegiatan porseni ini merupakan salah satu kegiatan GBKP yang diikuti oleh PERMATA (muda-mudi) GBKP yang menampilkan pertandingan landek (seni tari), Vokal Group dengan menggunakan perpaduan alat musik tradisional dan modern dan lain sebagainya. Dimana PERMATA (muda-mudi) akan saling bersaing menampilkan tarian dan vokal group terbaik dari tiap-tiap grup. Dalam kegiatan ini pemuda gereja yang berpakaian adat lengkap (rose) melakukan landek. Dengan demikian para pemuda tersebut sudah terjun 
langsung kedalam pengalaman kultural, dan sebagai penerus dapat merasakan dan diharapkan tumbuh rasa cinta akan budaya yang dimliki.

Selain dari seni tari GBKP juga melestarikan pakaian adat suku Karo. kegiatankegiatan porseni, pertandingan seni tari ini akan menampilkan seni tari dari masing-masing kelompok dan menggunakan pakaian adat lengkap suku Karo yaitu mulai dari ertudung(penutup kepala untuk perempuan), bulang-bulang (penutup kepala untuk laki-laki), uis nipes ( kain yang digunakan perempuan yang berbentuk ulos di budaya Batak Toba), bulang-bulang ( kain yang digunakan oleh lakilaki).

Selain dari seni tari dan pakain adat,GBKP juga masih melestarikan kesenian lain yaitu seni ukir seperti, ret-ret. Saat melakukan penelitan, peneliti sangat tertarik melihat keunikan dari salah satu gedung gereja yang sangat mencirikan bahwa gereja itu adalah gereja khas suku Karo. Gereja itu adalah gereja simpang enam kecamatan Kabanjahe. Tiangtiang teras gedung gereja tersebut berhiaskan ret-ret atau ukiran khas suku Karo. Ret-ret tersebut adalah kesenian khas suku Karo yang menghiasi setiap tiang teras yang memiliki arti khusus bagi masyrarakat Karo. Bertahannya Budaya Karo pada jemaat GBKP di Kecamatan Kabanjahe disebabkan karena kebudayaan yang dilestarikan merupakan kebudayaan yang tidak bertentangnan dengan ajaran GBKP dan masih bertumbuhnya kesadaran jemaat untuk melestarikan dan mempertahankan kebudayaannya.

\section{DAFTAR PUSTAKA}

Badan Pusat Statistik Kabupaten Karo. 2014. Kecamatan Kabanjahe Dalam Angka 2014. Berastagi: Badan Pusat Statistik Kabupaten Karo.

Damanik, H. 2013. Perkembangan Gereja Kristen Protestan Simalungun (GKPS) perbaungan (1977-2012). Medan: Unimed.

Darmadi, H. 2013. Metode Penelitian Pendidikan dan Sosial. Bandung: Alfabeta.
Departemen Pendidikan dan Kebudayaan. 2000, Kamus Besar BahasaIndonesia. Jakarta: Balai Pustaka.

Koentjaraningrat. 1981. Pengantar Ilmu Antropologi. Jakarta : Rineka Cipta. 2004. Manusia Dan Kebudayaan Di Indonesia. Jakarta: Djambatan.

Limbeng, J. 2012. Solidaritas GBKP (InternalEksternal). Kabanjahe: Moderamen Gereja Batak Karo Protestan.

Moderamen GBKP, 2010. Garis Besar Pelayanan Gereja Batak Karo Protestan 2010-2015. Kabanjahe: Moderamen GBKP.

Moleong, J.L., 2006. Metodologi Penelitian Kualitatif. Bandung: Remaja Rosdakarya Oofsset.

Simandjuntak, BA. 1986. Pemikiran Tentang Batak. Medan: Pusat Dokumentasi dan Pengkajian Kebudayaan Batak.

Sinulingga, A. 2012. Perjumpan Adat Karo dan Injil. Bekasi: Law Firm A.S Lingga SH \& Partners Advokat/Penasihat Hukum

Sinuraya, P. 2004. Bunga Rampai Sejarah Gereja Batak Karo Protestan (GBKP) jilid II. Medan: Merga Silima.

Soekanto, S. 2012. Sosiologi Suatu Pengantar. Jakarta: RajaGrafindo Persada.

Sugiyono. 2010. Metode Penelitian Kuantitatif Kualitatif dan $R \& D$. Jakarta: Raja Grafindo Persada.

Tarigan, S. 2008. Dinamika Orang Karo, Budaya dan Modernisme. Medan: Balai Adat Budaya Karo indonesia.

2011. Kepercayaan Orang Karo. Medan: Balai Adat Budaya Karo Indonesia. .2012. Mutiara Hijau Budaya Karo. Medan: Balai Adat Budaya karo Indonesia.

\section{Sumber Lain :}

http://sinta.ukdw.ac.id/sinta/resources/sintasrv/ni $\mathrm{m} / 21910269$

http://digilib.unimed.ac.id/persepsi-masyarakatdalam-melestarikan-nilainilai-budaya-karodi-desa-doulu-kecamatan-berastagikabupaten-karo-29816.html

http://bregedugetwita.blogspot.com/2010/01/dina mika-kebudayaan.html

(http://kaghoo.blogspot.com/2010/11/pengertianperanan.html).

http://www.karokab.go.id/in/

http://krisistia.blogspot.com/2013/03/apengertian-identitas-atau-jati-diri.html 